\title{
Antigenic Characterization of Brazilian Isolates of Anaplasma marginale
}

\author{
Jaqueline B Oliveira*, Claudio R Madruga/ ${ }^{+}$, Maria AM Schenk, Raul H Kessler, \\ Midori Miguita, Flábio R Araújo
}

\author{
Embrapa Gado de Corte, Caixa Postal 154, 79002-970 Campo Grande, MS, Brasil *Laboratório de Parasitologia, \\ Departamento de Biologia, Universidade Federal Rural de Pernambuco, Recife, PE, Brasil
}

\begin{abstract}
Antigenic characterization of Anaplasma marginale isolates, by identifying conserved and variable epitopes of major surface proteins (MSP), is an important tool for vaccine development against this rickettsia. The B cell epitopes of A. marginale isolates from three microregions of the State of Pernambuco and one from the State of Mato Grosso do Sul, Brazil, were characterized by indirect fluorescent antibody technique (IFAT) and Western blot (WB) with 15 monoclonal antibodies (MAbs). The epitope recognized by MAb ANA22B1 (MSP-1a) was conserved by IFAT and WB (73-81 kDa). MSP-2 epitopes recognized by MAbs ANAO58A2 and ANAO70A2 were conserved by IFAT, while ANAO50A2 and ANA66A2 epitopes were polymorphic; in the WB, the MAbs ANAO50A2 and ANAO70A2 identified bands of $45 \mathrm{kDa}$ only in the Pernambuco-Mata isolate. None of the isolates reacted with MAb ANAR75C2 (MSP-3). The MSP-4 epitope recognized by MAb ANAR76A1 was conserved by IFAT, as well as the MSP-5 epitope recognized by MAb ANAF16C1 by IFAT and WB (16 kDa). The MAbs ANAR17A6, ANAR83B3, ANAR94C1, ANAO24D5 and ANAR19A6 identified conserved epitopes by IFAT. MSP-1, MSP-2 and MSP-4, which previously showed partial protection in experimental trials, are also potential immunogens to be employed in Brazil, due to the B cell epitope conservation.
\end{abstract}

Key words: Anaplasma marginale - antigenic characterization - major surface protein - Brazil

Anaplasmosis is an important vector-borne hemoparasitic rickettsial disease of ruminant livestock in tropical and subtropical regions of the world (Visser et al. 1992). The disease, caused by Anaplasma marginale, an ehrlichial pathogen of the genogroup II, is characterized by fever, anemia, jaundice, weight loss, abortion, decreased milk production, and mortality during the acute phase of infection (Zaugg et al. 1985).

Immunization of calves with the outer membrane of $A$. marginale can induce complete protection from detectable rickettsemia against a virulent homologous challenge (Tebele et al. 1991). Therefore, strategies for the development of a safe and efficient immunization system may be directed towards a subunit vaccine, despite the $A$. marginale isolates from United States, Israel, Kenya, Japan, and Zimbabwe having shown virulence, morphologic, antigenic and genetic differences (Barbet et al. 1983).

The antigenic analysis of the outer membrane of initial bodies has shown six major surface proteins (MSP), which were recognized by sera from cattle infected with different isolates of $A$. marginale (Barbet et al. 1983, Palmer \& McGuire 1984, Palmer et al. 1985, 1986, Tebele et al. 1991, Oberle et al.1993). Some of them, such as the MSP1 complex, MSP-2, MSP-3 and MSP-4 have presented potential as immunogens, as reviewed by Palmer and McElwain (1995), or may be considered critical antigens,

${ }^{+}$Corresponding author. Fax: $+55-67-368.2150$. E-mail: madruga@cnpgc.embrapa.br

Received 2 October 2002

Accepted 18 February 2003 because some of them are associated with nutrient transport or erythrocyte adhesion and invasion mechanisms (McGarey et al. 1994).

The $\mathrm{B}$ cell and $\mathrm{T}$ cell activation is important for immunity against intra-erythrocytic pathogens, therefore $\mathrm{B}$ and $\mathrm{T}$ cell epitope conservation, including in MSPs encoded by multigene families such as MSP-2 and MSP-3 (Palmer et al. 1994, Alleman et al. 1997), may play an important role in the establishment of immunity.

This paper describes the characterization of $\mathrm{B}$ cell epitopes in four Brazilian isolates of $A$. marginale with a panel of monoclonal antibodies (MAbs) against surface antigens of initial bodies.

\section{MATERIALS AND METHODS}

A. marginale isolates and stabilates - Fifty microliters of blood from $A$. marginale carrier cattle raised in three endemic regions of the State of Pernambuco, Mata (PE-M), Agreste (PE-A), Sertão (PE-S), and of one region of the State of Mato Grosso de Sul, Campo Grande (MSCG), were inoculated in splenectomized Nellore calves (three animals for each region). These calves were negative for antibodies to $A$. marginale by indirect enzymelinked immunosorbent assay, performed as described by Madruga et al. (2000), and did not show detectable rickettsemia prior or after splenectomy. Stabilates were then prepared with blood of the inoculated calves during the acute infection and 10\% glycerol and cryopreserved in liquid nitrogen.

Indirect fluorescent antibody technique (IFAT) - For the preparation of IFAT antigen, blood samples with $8 \%$ (PE-M), 4\% (PE-A), 5.8\% (PE-S), and 5\% (MS-CG) rickettsemias were collected and washed three times in phosphate-buffered saline-PBS (10 mM Na2HPO4.2H2O, 
6.4 mM NaH2PO4.H2O, $100 \mathrm{mM} \mathrm{NaCl}$ ), pH 7.2 for plasma and buffy coat removal and then centrifuged at $1,090 \mathrm{x} \mathrm{g}$ for $10 \mathrm{~min}$ at $4^{\circ} \mathrm{C}$. Antigen slides were then prepared and stored at $-70^{\circ} \mathrm{C}$. The IFAT antigen slides were incubated during $30 \mathrm{~min}$ at $37^{\circ} \mathrm{C}$ with purified MAbs or MAbs from hybridoma supernatant or ascites. Following three washes with PBS, the slides were incubated for $30 \mathrm{~min}$ with goat anti-mouse IgG fluorescein isothiocyanate conjugate (Sigma). The slides were washed three times, dried and examined by epifluorescent microscopy.

Western blot (WB) - Calf red blood cells (RBC) infected with PE-M, PE-A, PE-S and MS-CG isolates, showing $60 \%$, $31 \%, 40 \%$ and $72 \%$ rickettsemias, respectively, were disrupted chemically $(100 \mathrm{mM}$ tris, $10 \mathrm{mM}$ EDTA, $0.2 \mathrm{mM} \mathrm{N}$ p-tosyl-L-lysil chloromethyl ketone, $2 \mathrm{mM}$ phenylmethyl sulfonylfluoride and 2\% tergitol NP-40) and by sonication $(100 \mathrm{~W})$ for $10 \mathrm{~min}$. The lysed RBCs were centrifuged and filtered as previously described by Palmer and McGuire (1984). The protein concentrations of these antigens, determined by bicinchoninic acid assay (Smith et al. 1985), were $7.3 \mu \mathrm{g} / \mathrm{ml}$ (PE-M), $21.3 \mu \mathrm{g} / \mathrm{ml}$ (PE-A), 23.9 $\mu \mathrm{g} / \mathrm{ml}$ (PE-S) and $20.2 \mu \mathrm{g} / \mathrm{ml}$ (MS-CG).

Electrophoresis of Anaplasma soluble antigens was performed on a SDS- $10 \%$ polyacrilamide gel, and proteins were transferred to a nitrocellulose membrane through a semi-dry system. The membrane was blocked overnight ( $0.01 \mathrm{M}$ tris base, $0.15 \mathrm{M} \mathrm{NaCl}, 0.05 \%$ tween- $20,5 \%$ skim milk), and then incubated for $4 \mathrm{~h}$ with MAbs diluted 1:50 and washed in blocking solution. Bound antibody was detected with goat anti-mouse $\operatorname{IgG}$ peroxidase conjugate diluted 1:500, followed by diamine benzoic acid solution (1 mg/ml).

MAbs - The MAbs employed in this work were produced and initially screened by Davis et al. (1981). Some of these MAbs were characterized as recognizing epitopes of MSPs, such as ANA22B1, which reacts with epitope on MSP-1a (Palmer et al. 1986), ANAR38A6 (MSP-1b) (Barbet \& Allred 1991), ANAO50A2, ANAO58A2, ANAO66A2, and ANAO70A2 (MSP-2) (Palmer et al. 1985), ANAG75C2 (MSP-3) (McGuire et al. 1991), ANAG76A1 (MSP-4) (Oberle et al. 1993), and ANAF16C1 (MSP-5) (Visser et al. 1992). A panel of MAbs, ANAR17A6, ANAR83B3, ANAR94C1, ANAO24D5, and ANAR19A6, which recognize isolate restricted epitopes (McGuire et al. 1984), was also used in this work. The MAb TRYP1E1, anti-variable surface glycoprotein (VSG) of Trypanosoma brucei was employed as a negative control in the IFAT and WB.

\section{RESULTS}

Antigenic analysis by IFAT - Antigenic analysis of Brazilian A. marginale isolates by IFAT showed epitope conservation of MSP-1a, MSP-1b, MSP-4 and MSP-5 in all Brazilian isolates (Table I). Some of MSP-2 B cell epitopes were conserved among all isolates, such as those recognized by ANAO58A2 and ANAO70A2, while the MAbs ANAO50A2 and ANAO66A2 reacted with epitopes only in the PE-M and MS-CG isolates. No reactivity occurred with MAb ANAR75C2, directed to MSP-3. The group of isolate-restricted MAbs (ANAR17A6, ANAR83B3, ANAR94C1, ANAO24D5, and ANAR19A6) identified conserved B cell epitopes in all isolates (Table II) and MAb ANAO24D5 displayed an "appendage" in the PE-S and MS-CG isolates (Fig. 1).

Antigenic analysis by $W B$ - The major polypeptide bands identified by MAb ANA22B1 (MSP-1a) in WB had apparent molecular weights of $81 \mathrm{kDa}$ in the PE-M, $80 \mathrm{kDa}$ in the PE-A, $73 \mathrm{kDa}$ in the PE-S and $78 \mathrm{kDa}$ in the MS-CG isolates (Fig. 2). Other secondary bands were visualized with antigens of all isolates. The MAb ANAR38A6 (MSP1b) did not react with antigen of any isolate (data not shown).

The MAbs ANAO50A2 and ANAO70A2 (MSP-2) were able to identify bands of apparent molecular weights of $45 \mathrm{kDa}$ in the PE-M isolate. No reactions of these MAbs

\section{TABLE I}

Reactivity of Brazilian isolates of Anaplasma marginale with a panel of monoclonal antibodies (MAb) against initial bodies' major surface proteins (MSP) in the indirect fluorescent antibody technique

\begin{tabular}{lccccc}
\hline & \multirow{2}{*}{$\begin{array}{c}\text { Recognized } \\
\text { Mab }\end{array}$} & MSP & PE-M & PE-A & PE-S MS-CG \\
\cline { 3 - 7 } ANA22B1 & MSP-1a & + & + & + & + \\
ANAR38A6 & MSP-1b & + & + & + & + \\
ANAO50A2 & MSP-2 & + & - & - & + \\
ANA058A2 & MSP-2 & + & + & + & + \\
ANAO66A2 & MSP-2 & + & - & - & + \\
ANA070A2 & MSP-2 & + & + & + & + \\
ANAR75C2 & MSP-3 & - & - & - & - \\
ANAR76A1 & MSP-4 & + & + & + & + \\
ANAF16C1 & MSP-5 & + & + & + & - \\
TRYP1E1 & $\begin{array}{l}\text { Variable surface } \\
\text { glycoprotein of }\end{array}$ & & - & - & - \\
\multicolumn{5}{c}{ Trypanosoma } \\
brucei
\end{tabular}

PE-M: Penambuco-Zona da Mata; PE-A: Pernambuco-Agreste; PE-S: Pernambuco-Sertão; MS-CG: Mato Grosso do Sul-Campo Grande

\section{TABLE II}

Reactivity of Brazilian isolates of Anaplasma marginale with a panel of monoclonal antibodies (MAb) considered as recognizing isolate-restricted B-cell epitopes in the indirect fluorescent antibody technique

\begin{tabular}{lcccc}
\hline & \multicolumn{4}{c}{ MAbs Brazilian isolates of A. marginale } \\
\cline { 2 - 5 } & PE-M & PE-A & PE-S & MS-CG \\
\hline ANAR17A6 & + & + & + & + \\
ANAR83B3 & + & + & + & + \\
ANAR94C1 & + & + & + & + \\
ANAO24D5 & + & + & + & + \\
ANAR19A6 & + & + & + & + \\
TRYP1E1 & Variable surface & - & - & - \\
\multicolumn{5}{c}{ glycoprotein of } \\
Trypanosoma & & & \\
brucei & & & \\
\hline
\end{tabular}

PE-M: Penambuco-Zona da Mata; PE-A: Pernambuco-Agreste; PE-S: Pernambuco-Sertão; MS-CG: Mato Grosso do Sul-Campo Grande 


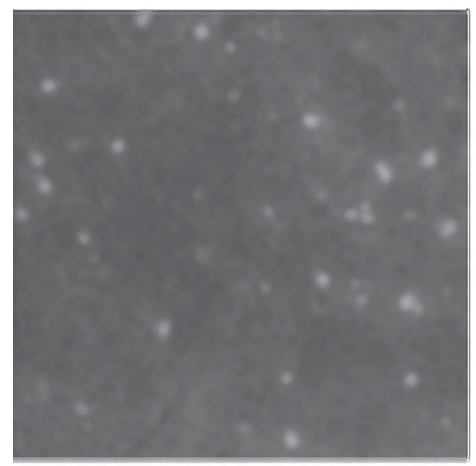

a

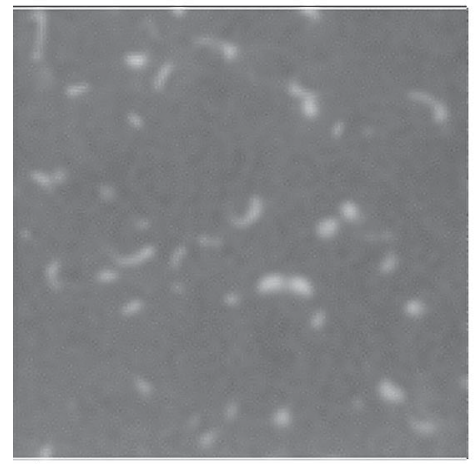

d

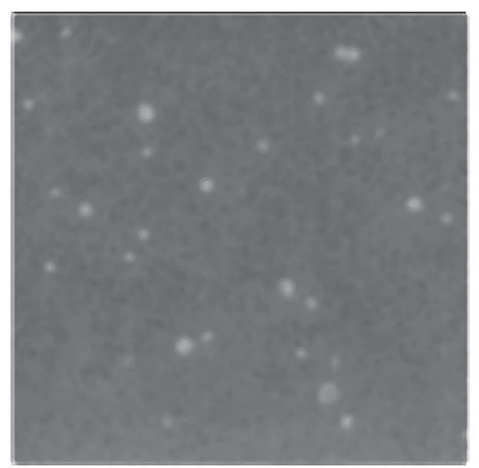

$\mathrm{b}$

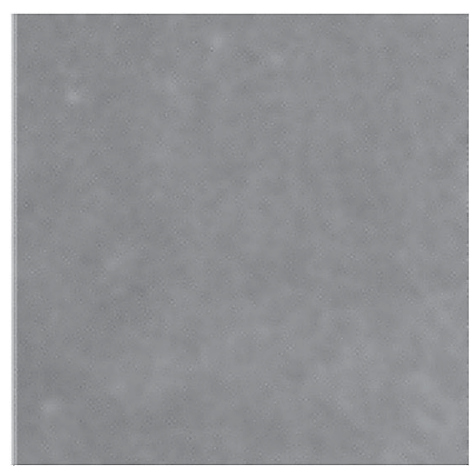

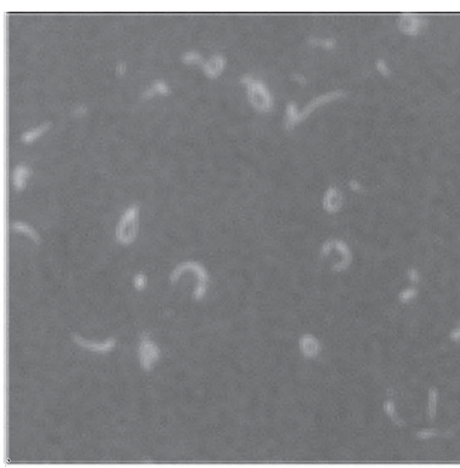

C

e

Fig. 1: immunofluorescent antibody test with antigens from Brazilian isolates of Anaplasma marginale with monoclonal antibody ANAO24D5; a: Pernambuco-Zona da Mata; b: Pernambuco-Agreste; c: Pernambuco-Sertão; d: Mato Grosso do Sul-Campo Grande; e: negative control, monoclonal antibody TRYP1E1 to variable surface glycoprotein of Trypanosoma brucei - Pernambuco Zona da Mata isolate (the pattern or reactivity was the same for the other isolates). Arrows indicate the "appendage" forms of A. marginale.

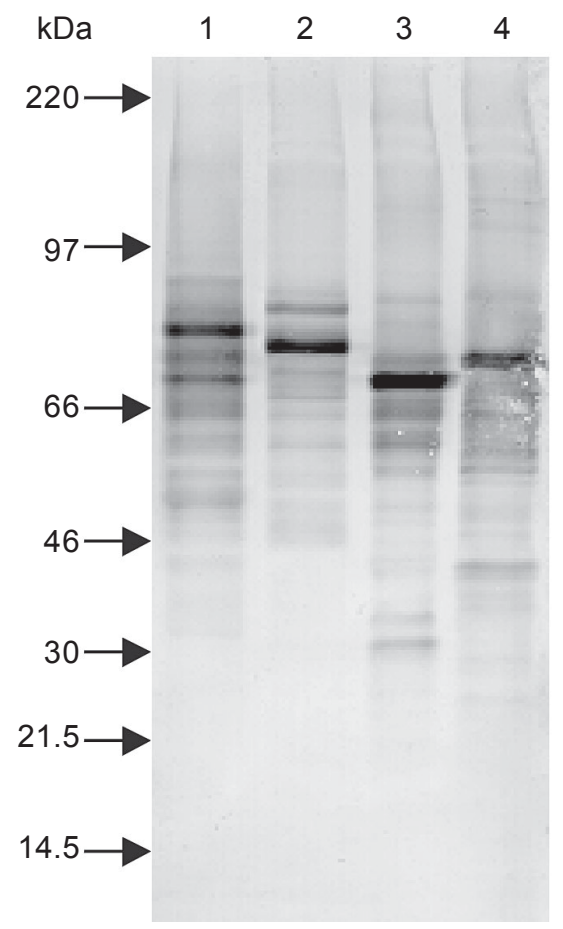

Fig. 2: Western blot with antigens from Brazilian isolates of Anaplasma marginale with monoclonal antibody ANA22B1. Lanes 1: Pernambuco-Zona da Mata; 2: Pernambuco-Agreste; 3: Pernambuco-Sertão; 4: Mato Grosso do Sul-Campo Grande were observed with other isolates. The MAbs ANAO58A2 and ANAO66A2 (MSP-2) were not tested in the WB. The MAbs ANAR75C2 (MSP-3) and ANAR76A1 (MSP-4) did not react with any isolate (data not shown). MAb ANAF16C1 (MSP-5) identified polypeptides bands of 16 $\mathrm{kDa}$ in all isolates (Fig. 3). The WB with the ANAO24D5 displayed size polymorphism, since this isolate-restricted $\mathrm{MAb}$ reacted with bands of apparent molecular weight of $35 \mathrm{kDa}$ in PE-M isolate, $30 \mathrm{kDa}$ in PE-A isolate and $40 \mathrm{kDa}$ and $46 \mathrm{kDa}$ in MS-CG isolate (Fig. 4). This MAb did not react with $\mathrm{PE}-\mathrm{S}$ isolate.

\section{DISCUSSION}

The antigenic evaluation of Brazilian isolates of $A$. marginale confirmed prior investigations of the MSP-1 complex, which revealed conservation of the neutralization-sensitive B cell epitope among isolates from United States, Israel, Kenya (Palmer et al. 1988a) and Zimbabwe (Tebele et al. 1991). The size polymorphism of the bands recognized by MAb ANA22B1 among the Brazilian isolates is explained by the variable number of tandem repeats which contains the MSP-1a epitope recognized by this MAb in each isolate (Allred et al. 1990). The MSP-1b epitope conservation in the PE-M, PE-A, PE-S, and MS$\mathrm{CG}$ isolates determined by IFAT is in agreement with the observation that this polypeptide has shown minimal interstrain polymorphism (Barbet \& Allred 1991). The msp $1 \beta$ entire gene family was cloned and sequenced from 


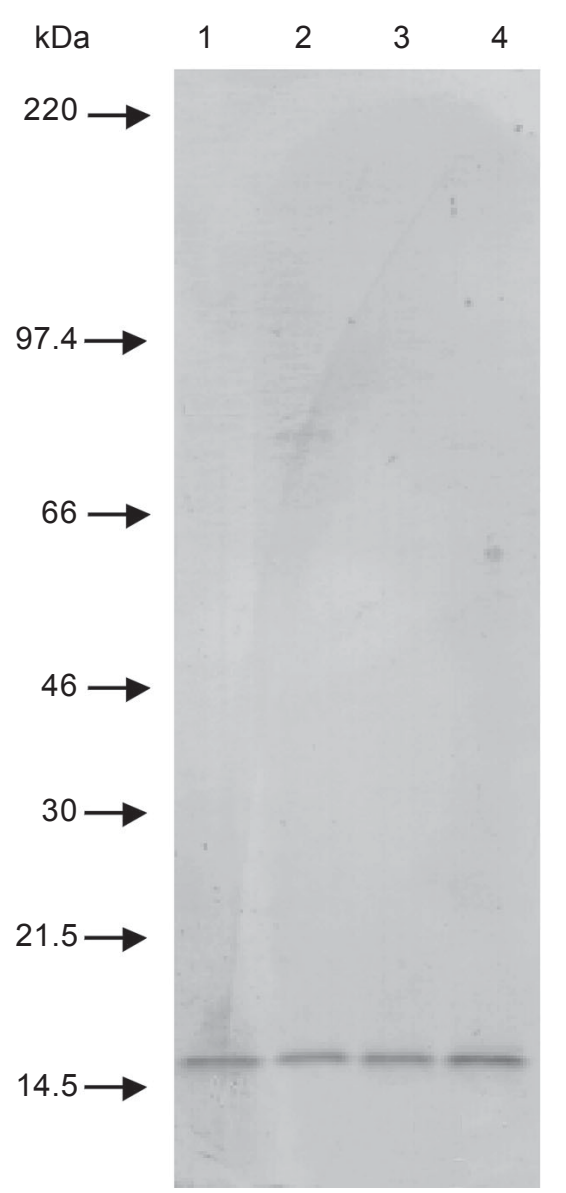

Fig. 3: Western blot with antigen from Brazilian isolates of Anaplasma marginale with monoclonal antibody ANAF16C1. Lanes 1: Pernambuco-Zona da Mata; 2: Pernambuco-Agreste; 3: Pernambuco-Sertão; 4: Mato Grosso do Sul-Campo Grande

a Florida isolate of $A$. marginale and two full-length genes were identified and designated as msp $1 \beta 1$ and msp $1 \beta 2$ (Viseshakul et al. 2000). Both $m s p 1 \beta 1$ and $m s p 1 \beta 2$ genes were transcribed into different, partially homologous mRNAs. Interestingly, another analysis (Camacho-Nuez et al. 2000) of the same Florida isolate by PCR failed to detect $m s p 1 \beta 2$ but found three other full length, expressed msp $1 \beta 1$ genes not detected by Viseshakul et al. (2000).

Further work by Bowie et al. (2002) did not confirm these findings. Analysis of Florida and Oklahoma isolates of $A$. marginale using primers specific for each of the two genes resulted in the amplification of that gene and no other $m s p l \mathrm{~b}$ gene. The msplb genes between isolates had an amino acid similarity of $96 \%$ for MSP- $1 \beta 1$ and $92 \%$ for MSP- $1 \beta 2$. These authors stated that CamachoNuez et al. (2000) probably identified mosaics of the known genomic copies msp $1 \beta 1$ and $m s p 1 \beta 2$, that represent minor polymorphic sequences present in a rickettsial population.

Because the proteins expressed by $m s p l \mathrm{a}$ and $m s p l \mathrm{~b}$ genes are involved in adherence of $A$. marginale to bovine erythrocyte and tick cell receptors (McGarey et al. 1994), the conservation of these genes and their respective proteins (Bowie et al. 2002) suggests that they may

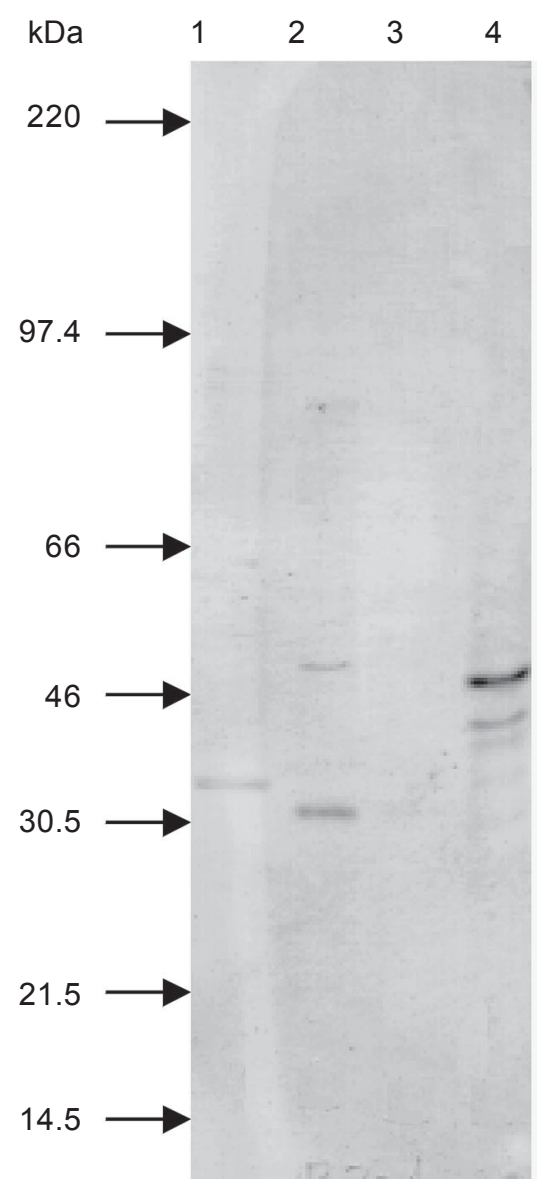

Fig. 4: Western blot with antigens from Brazilian isolates of Anaplasma marginale with monoclonal antibody ANAO24D5. Lanes - 1: Pernambuco-Zona da Mata; 2: Pernambuco-Agreste; 3: Pernambuco-Sertão; 4: Mato Grosso do Sul-Campo Grande

be useful in the development of recombinant vaccines for anaplasmosis.

The MSP-2 B cell epitope variation in the Brazilian isolates of $A$. marginale is partially in conformity with $m s p 2$ gene structure and expression. This gene has a central hypervariable region that contains highly immunogenic $\mathrm{B}$ cell epitopes that induce variant specific antibodies, which are associated with $A$. marginale clearance (French et al. 1998). The MSP-2 polymorphism has been demonstrated mainly during the acute infection phase (Eid et al. 1996) period, when the antigens for IFAT and WB were obtained, and in the cyclic rickettsemia of chronically infected animals (French et al. 1998). The conservation of some $\mathrm{B}$ cell epitopes among Brazilian A. marginale isolates was also verified in isolates from the United States (Virginia, Florida, Texas, Idaho, and Washington) (McGuire et al. 1984, Palmer et al. 1985), Kenya, Israel, and Zimbabwe (Palmer et al. 1988a, Tebele et al. 1991). This conservation may be related to the highly conserved $\mathrm{N}$ and $\mathrm{C}$ terminal regions of the polypeptide coded by $m s p-2$ gene (Brown et al. 2001), although the minimal surface exposure due to its hydrophobic characteristic (membrane domain) (French et al. 1999). However, the homologous and heterologous protection conferred by native MSP-2 
(Palmer et al. 1988b) suggests the importance of conserved $\mathrm{B}$ and $\mathrm{T}$ cell epitopes in the production of an efficient immune response.

Although MSP-3 was previously considered as conserved among different $A$. marginale isolates (McGuire et al. 1991), antigenic variation of this major surface protein was observed in North American isolates (Alleman \& Barbet 1996) and in the African isolate (Tebele et al. 1991). The $m s p$-3 gene was later characterized as polymorphic (Alleman et al. 1997). These findings can explain the absence of MSP-3 epitope recognition by MAb ANAG75C2 in the Brazilian isolates of $A$. marginale.

The positive reactions of the MAb ANAR76A1 in the IFAT with B-cell epitope of MSP-4 characterizing conservation in the Brazilian A. marginale isolates is in agreement with studies with other isolates of $A$. marginale (Oberle et al. 1993). This major surface protein is encoded by a single copy gene, which constrains gene recombination (Oberle et al. 1993). Additionally, MSP-4 possibly acts as an adhesin and could have a crucial function for Anaplasma spp. erythrocyte invasion (McGarey et al. 1994). The non-linear epitope recognized by MAb ANAR76A1 (Oberle et al. 1993) may explain the absence of reaction in WB.

The MSP-5 epitope conservation in the Brazilian isolates is in agreement with other $A$. marginale geographical isolates and with the hypothesis that this polypeptide has also a fundamental function in the biological cycle of Anaplasma organisms. It is present during the acute and chronic phases of the bovine infection, as well as in $A$. centrale and A. ovis (Visser et al. 1992, Knowles et al. 1996).

In contrast with the $A$. marginale isolates from the United States, Kenya, and Israel that showed B cell epitope diversity with the MAbs ANAR17A6, ANAR83B3, ANAR94C1, ANAO24D5, and ANAR19A6 (McGuire et al. 1984), the Brazilian isolates exhibited epitope conservation with them. In the WB, the MAb ANAO24D5 showed polypeptide size polymorphism in the four Brazilian isolates studied. This apparent molecular size variation indicates that the polypeptide epitope recognized by MAb ANAO24D5 is neither MSP-2 nor MSP-4. The MSP2 has minimal size polymorphism, around 9\% (Palmer et al. 1988b) and MSP4 did not change in apparent molecular size in all isolates tested (Oberle et al. 1993). The tailed form described in the majority of North American $A$. marginale isolates in the IFAT with ANAO24D5 (McGuire et al. 1984) was also observed in two studied isolates, PE$\mathrm{S}$ and MS-CG. This appendage was described as actin filaments, responsible for motility of some bacteria, which improve their intra and inter-cellular propagation and consequently enhance infection dissemination (Cossart \& Lecuit 1998).

Despite the MSP-2 genetic and antigenic polymorphism, this protein and MSP1 in their native forms as well as in the outer membrane of $A$. marginale initial bodies were able to induce an efficient immune protection against homologous and heterologous challenges (Palmer et al. 1988a, 1989, Tebele et al. 1991). These data suggest the importance of $\mathrm{B}$ and $\mathrm{T}$ cell epitope conservation. Likewise the $\mathrm{B}$ cell conservation, the $\mathrm{T}$ cell epitope conserva- tion has also been described, even in MSPs coded by multigene family such as MSP-2 and MSP-3 (Brown et al. 1998b).

The CD4 T cell type I response with interferon-g production and resultant macrophage activation has been associated with immunity against intra-erythrocytic pathogens (Brown et al. 1998a, 2001). The Th1 response also stimulates immunoglobulin $\mathrm{G}_{2}$ isotype production by $\mathrm{B}$ cells, which increases opsonization and consequently the phagocytosis by activated macrophages (Brown et al. 1998a). Therefore, B cell epitope conservation between and within strains is crucial for the Anaplasma clearance because antibody specificity is important in this process.

Despite the small number of $A$. marginale isolates tested, which are not representative of all regions of Brazil, the B cell epitope conservation on MSP-1 complex and some epitopes on MSP-2 shown in this study and the information that they previously showed partial protection against $A$. marginale infection (Palmer \& McElwain 1995), suggest that these polypeptides are potential immunogens to be used in Brazil. On the other hand, MSP-5 can be utilized as antigens for diagnostic serological test due to $\mathrm{B}$ cell epitope conservation among the isolates studied.

\section{ACKNOWLEDGEMENTS}

To Dr Guy Palmer from Washington State University for providing the monoclonal antibodies.

\section{REFERENCES}

Alleman AR, Barbet AF 1996. Evaluation of Anaplasma marginale major surface protein 3 (MSP3) as a diagnostic test antigen. J Clin Microbiol 34: 270-276.

Alleman AR, Palmer GH, McGuire TC, McElwain TF, Perryman LE, Barbet AF 1997. Anaplasma marginale major surface protein 3 is encoded by a polymorphic, multigene family. Infect Immun 65: 156-163.

Allred DR, McGuire TC, Palmer GH, Leib SR, Harkins TM, McElwain TF, Barbet AF 1990. Molecular basis for surface antigen size polymorphisms and conservation of a neutralization-sensitive epitope in Anaplasma marginale. Proc Natl Acad Sci USA 87: 3220-3224.

Barbet AF, Allred DR 1991. The msp1 $\beta$ multigene family of Anaplasma marginale: nucleotide sequence analysis of an expressed copy. Infect Immun 59: 971-976.

Barbet AF, Anderson LW, Palmer GH, McGuire TC 1983. Comparison of proteins synthesized by two different isolates of Anaplasma marginale. Infect Immun 40: 1068-1074.

Bowie MV, de la Fuente J, Kocan KM, Blouin EF, Barbet AF 2002. Conservation of major surface protein 1 genes of Anaplasma marginale during cyclic transmission between ticks and cattle. Gene 282: 95-102.

Brown WC, McGuire TC, Zhu D, Lewin HA, Sosnow J, Palmer GH 2001. Highly conserved regions of the immunodominant major surface protein 2 of the genogroup II ehrlichial pathogen Anaplasma marginale are rich in naturally derived CD4+ $\mathrm{T}$ lymphocyte epitopes that elicit strong recall responses. J Immunol 166: 1114-1124.

Brown WC, Shkap V, Zhu D, McGuire TC, Tuo W, McElwain TF, Palmer GH 1998a. CD4+ T-lymphocyte and immunoglobulin G2 responses in calves immunized with Anaplasma marginale outer membranes and protected against homologous challenge. Infect Immun 66: 5406-5413.

Brown WC, Zhu D, Shkap V, McGuire TC, Blouin EF, Kocan KM, Palmer GH 1998b. The repertoire of Anaplasma 
marginale antigens recognized by CD4+ T-lymphocyte clones from protectively immunized cattle is diverse and includes major surface protein 2 (MSP-2) and MSP-3. Infect Immun 66: 5414-5422.

Camacho-Nuez M, de Lourdes Munoz M, Suarez CE, McGuire TC, Brown WC, Palmer GH 2000. Expression of polymorphic msp $1 \beta$ genes during acute Anaplasma marginale rickettsemia. Infect Immun 68: 1946-1952.

Cossart P, Lecuit M 1998. Interactions of Listeria monocytogenes with mammalian cells during entry and actin-based movement: bacterial factors, cellular ligands and signaling, cellular ligands and signaling. EMBOJ 17: 3797-3806.

Davis WC, McGuire TC, Anderson LW, Banks KL, Seifert SD, Johnson MI 1981. Development of monoclonal antibodies to Anaplasma marginale and preliminary studies on their application. In 7 National Anaplasmosis Conference, Mississipi, USA, Proceedings, p. 285.

Eid G, French DM, Lundgren AM, Barbet AF, McElwain TF, Palmer GH 1996. Expression of major surface protein 2 antigenic variants during acute Anaplasma marginale rickettsemia. Infect Immun 64: 836-841.

French DM, Brown WC, Palmer GH 1999. Emergence of Anaplasma marginale antigenic variants during persistent rickettsemia. Infect Immun 67: 5834-5840.

French DM, McElwain TF, McGuire TC, Palmer GH 1998. Expression of Anaplasma marginale major surface protein 2 variants during persistent cyclic rickettsemia. Infect Immun 66: 1200-1207.

Knowles D, Torioni de Echaide S, Palmer G, McGuire T, Stiller D, McElwain T 1996. Antibody against an Anaplasma marginale MSP5 epitope common to tick and erythrocyte stages identifies persistently infected cattle. J Clin Microbiol 34: $2225-2230$

Madruga CR, Marques APC, Leal CRB, Carvalho CME, Araújo FR, Kessler RH 2000. Evaluation of an enzyme-linked immunosorbent assay to detect antibodies against Anaplasma marginale. Pesq Vet Bras 20: 109-112.

McGarey DJ, Barbet AF, Palmer GH, McGuire TC, Allred DR 1994. Putative adhesins of Anaplasma marginale: major surface polypeptides 1a and 1b. Infect Immun 62: 45944601.

McGuire TC, Davis WC, Brassfield AL, McElwain TF, Palmer GH 1991. Identification of Anaplasma marginale long-term carrier cattle by detection of serum antibody to isolated MSP-3. J Clin Microbiol 29: 788-793.

McGuire TC, Palmer GH, Goff WL, Johnson MI, Davis WC 1984. Common and isolate-restricted antigens of Anaplasma marginale detected with monoclonal antibodies. Infect Immun 45: 697-700.

Oberle SM, Palmer GH, Barbet AF 1993. Expression and immune recognition of the conserved MSP4 outer membrane protein of Anaplasma marginale. Infect Immun 61: 52455251.

Palmer GH, McElwain TF 1995. Molecular basis for vaccine development against anaplasmosis and babesiosis. Vet Parasitol 57: 233-253.

Palmer GH, McGuire TC 1984. Immune serum against Anaplasma marginale initial bodies neutralizes infectivity for cattle. J Immunol 133: 1010-1015.

Palmer GH, Barbet AF, Cantor GH, McGuire TC 1989. Immunization of cattle with the MSP-1 surface protein complex induces protection against a structurally variant Anaplasma marginale isolate. Infect Immun 57: 3666-3669.

Palmer GH, Barbet AF, Davis WC, McGuire TC 1986. Immunization with an isolate-common surface protein protects cattle against anaplasmosis. Science 231: 1299-1302.

Palmer GH, Barbet AF, Kuttler KL, McGuire TC 1986. Detection of an Anaplasma marginale common surface protein present in all stages of infection. J Clin Microbiol 23: 10781083.

Palmer GH, Barbet AF, Musoke AJ, Katende JM, Rurangirwa F, Shkap V, Pipano E, Davis WC, McGuire TC 1988a. Recognition of conserved surface protein epitopes on Anaplasma centrale and Anaplasma marginale isolates from Israel, Kenya and the United States. Int J Parasitol 18: 33-38.

Palmer GH, Eid G, Barbet AF, McGuire TC, McElwain TF 1994. The immunoprotective Anaplasma marginale major surface protein 2 is encoded by a polymorphic multigene family. Infect Immun 62: 3808-3816.

Palmer GH, Kocan KM, Barron SJ, Hair JA, Barbet AF, Davis WC, McGuire TC 1985. Presence of common antigens, including major surface protein epitopes, between the cattle (intraerythrocytic) and tick stages of Anaplasma marginale. Infect Immun 50: 881-886.

Palmer GH, Oberle SM, Barbet AF, Goff WL, Davis WC, McGuire TC 1988b. Immunization of cattle with a 36kilodalton surface protein induces protection against homologous and heterologous Anaplasma marginale challenge. Infect Immun 56: 1526-1531.

Smith PK, Krohn RI, Hermanson GT, Mallia AK, Gartner FH, Provenzano MD, Fujimoto EK, Goeke NM, Olson BJ, Klenk DC 1985. Measurement of protein using bicinchoninic acid. Anal Biochem 150: 76-85.

Tebele N, McGuire TC, Palmer GH 1991. Induction of protective immunity by using Anaplasma marginale initial body membranes. Infect Immun 59: 3199-3204.

Viseshakul N, Kamper S, Bowie MV, Barbet AF 2000. Sequence and expression analysis of a surface antigen gene family of the rickettsia Anaplasma marginale. Gene 253: 45-53.

Visser ES, McGuire TC, Palmer GH, Davis WC, Shkap V, Pipano E, Knowles Jr DP 1992. The Anaplasma marginale msp 5 gene encodes a 19-kilodalton protein conserved in all recognized Anaplasma species. Infect Immun 60: 5139-5144.

Zaugg JL, Stiller D, Coan ME, Lincoln SD 1986. Transmission of Anaplasma marginale Theiler by males of Dermacentor andersoni Stiles fed on an Idaho field-infected, chronic carrier cow. Am J Vet Res 47: 2269-2271. 